\title{
中亚地区晚古生代腕足动物古生物地理与构造 古地理的协同演化
}

\author{
王成文 ${ }^{(1)}$ ，赵国伟 ${ }^{1}$ ，李宁 ${ }^{1}$ ，宗普 ${ }^{2}$ \\ (1) 吉林大学地球科学学院, 长春 130061 ; \\ (2) 中国地质科学院地质研究所, 北京 100037 \\ *E-mail: wangcw@jlu.edu.cn \\ 收稿日期: 2012-11-14; 接受日期: 2013-04-15; 网络版发表日期: 2013-12-25 \\ 中国地质调查局项目 (编号: 1212011120153-3)资助
}

\begin{abstract}
摘要在早泥盆世、早石炭世、晚石炭世、早二叠世、中二叠世等腕足动物古生物地理区 划研究基础上, 通过对比分析, 揭示了中亚地区晚古生代腕足动物古生物地理与构造古地理 的协同演化关系, 既较为合理解释了此地此时腕足动物古生物地理形成的机制, 又为此地此 时洋、陆位置及其配置关系研究提供了依据.
\end{abstract}

关键词 中亚地区 晚古生代 腕足动物 生物地理 构造古地理 协同演化
东欧板块、西伯利亚板块、华北板块、塔里木地 块之间的这一广䘚地区被称作中亚造山带(Khain, 1985; Zonenshain 等, 1990; Badarch 等, 2002; Gordienko, 2006), 本文称之为中亚地区.

中亚造山带是全球地质历史上最为宏大的造山 带, 有着复杂的构造演化历史; 中亚地区发育有丰富 的腕足动物化石, 其古生物地理变化丰富多彩. 中亚 地区及其所含的腕足动物是古生物地理与构造古地 理协同演化研究的理想地区与化石门类.

古生物地理学为大陆漂移和板块构造理论的发 展提供了关键证据(Hallam, 1981; 王乃文, 1984). 古 生物地理信息在大陆岩石圈板块构造重建中具有重 要作用 (王鸿祯, 1981; 殷鸿福, 1988; Scotese 等, 1990; 王鸿祯等, 1990; 陈旭等, 2001; Boucot 等, 2009). 由于缺乏对古生物地理区与构造古地理协同
演化的深入理解, 将古生物地理信息机械套用, 常导 致偏差. 本文虽无力解决这一重大问题，但还是希望 为解决这类问题探索一条有效的途径.

古生物地理学研究面对两项最基本的任务, 既 要确定古生物的地理分布图样(任何种类的)一一古生 物地理区的划分; 又要探讨形成该种图样的原因一 形成机制(王成文, 1994b). 中亚地区腕足动物古生物 地理区系研究中存在许多问题, 这些问题仅从地理 区自身考虑难以寻受到圆满答案. 从古生物地理与 构造古地理协同演化关系分析, 可能更有利于揭示 其中的奥秘.

古生物地理与构造古地理协同演化研究, 得益 于近些年来兴起的地球系统科学和地球生物学的理 念. 地球系统科学将地球各圈层作为一个系统, 研究 各圈层的相互作用过程. 地球生物学是研究地球生

中文引用格式: 王成文, 赵国伟, 李宁, 等. 2014. 中亚地区晚古生代腕足动物古生物地理与构造古地理的协同演化. 中国科学: 地球科学, 44: 213-226

英文引用格式: Wang C W, Zhao G W, Li N, et al. 2013. Coevolution of brachiopod paleobiogeography and tectonopaleogeography during the late Paleozoic in Central Asia. Science China: Earth Sciences, 56: 2094-2106, doi: 10.1007/s11430-013-4670-x 
物圈与其他圈层相互作用的科学 (Noffke, 2005; Bottjer, 2005; 谢树成等, 2006; 殷鸿福等, 2009). 不 同地质时期的构造古地理一一洋、陆位置及其配置关 系和古生物地理分布的演化分别是岩石圈板块构造 演化和生物圈演化的重要表现形式. 古生物地理与 构造古地理协同演化研究是地球生物学的一个重要 研究领域(Lieberman, 2005).

\section{1 晚古生代中亚地区基本构造轮廓}

本文首先简要介绍用于对比分析的中亚地区晚 古生代基本构造轮廓. 这一地区晚古生代构造十分 复杂，经过简化，基本可以分出如下几个主要的构造 单元(图 1(a) 5(a)).

贯穿中亚造山带核心部位的额尔齐斯-中蒙古鄂霍次克缝合带以北地区常称为西伯利亚克拉通的 前晚古生代拼贴带, 亦称做西伯利亚板块的镶嵌构 造区(Wang 等, 2011). 晚里菲至加里东期增生到西伯 利亚板块上的有东萨彦、奥洛吉特、阿加尔达格、巴 捷涅夫揳、东图瓦、库兹涅兹阿拉套、萨拉伊尔、阿 尔泰山、蒙古阿尔泰等褶皱带(Mossakovsky 等, 1993). 尽管有单一岩浆弧拼贴和多个地体拼贴的不同构造 模式, 但是均认为这些褶皱带是在晚古生代之前 不同时期拼贴到西伯利亚克拉通之上，构成了晚古 生代西伯利亚板块南缘(Wang 等, 2011)(现代地理 位置).

额尔齐斯-中蒙古-鄂霍次克缝合带以南是中亚 造山带主体部分. 东段由佳-蒙地块组成, 佳-蒙地块 是北由蒙古-鄂霍次克缝合带、南由西拉木伦-延吉缝 合带、东由中锡霍特俯冲带所围限的一个晚古生代大 地构造单元(王成文等, 2009, 2008; Wang 等, 2011). 西段由哈萨克斯坦板块组成, 哈萨克斯坦板块主要 由汉特-曼西斯克、阿塔苏-莫因特、哈萨克斯坦-北天 山等微地块组成(Zonenshain 等, 1990). 阿塔苏-莫因 特微地块亦称巴尔喀什微地块, 或称巴尔喀什-准噶 尔地块(成守德等, 2009). 哈萨克斯坦板块的东界为 额尔齐斯缝合带(李春昱等, 1982; Zonenshain 等, 1990; 王鸿祯等，1990; Mossakovsky 等，1993; 任纪 舜等, 2002; Wang 等, 2011); 西界为瓦列利亚诺夫斯 克火山岩带(Zonenshain 等, 1990); 南界为南天山缝 合带(Zonenshain 等, 1990; 李春昱等, 1982). 南天山 缝合带西延即阴山缝合带, 合称天山-阴山缝合带
(Yin 等, 1996), 亦称南天山-北山-西拉木伦缝合带 (Wang 等, 2012). 这条巨型缝合带将中亚造山带与华 北板块、塔里木地块分开, 亦是中亚造山带的南部边 界带.

\section{2 早泥盆世(Lochkovian-Emsian)腕足动物 古生物地理与构造古地理的协同演化}

\section{1 古生物地理区划的研究现状}

中亚地区早泥盆世腕足动物群主要分布在乌拉 尔-南天山、萨拉伊尔-萨彦、巴尔喀什-准噶尔、大小兴安岭等地区(图 1(a)).

中亚地区早泥盆世腕足动物群的古生物地理区 划长期以来受到人们的关注，有多种划分方案：老世 界区乌拉尔亚区(Boucot 等, 1969); 乌拉尔-天山、阿 尔泰-萨彦、准噶尔-巴尔喀什和蒙古-鄂霍次克等 4 个区(Hamada, 1971); 老世界大区的乌拉尔和蒙古-鄂 霍次克域，巴尔喀什地区腕足动物群置于乌拉尔域 (Boucot, 1974); 巴尔喀什-蒙古-鄂霍次克域和南天山 域(含乌拉尔地区), 阿尔泰-萨彦地区的腕足动物群 置于巴尔喀什-蒙古-鄂霍次克域(Hou 等, 1990); 老世 界大区的乌拉尔域和巴尔喀什-蒙古-鄂霍次克域, 库 兹涅兹盆地腕足动物群属于乌拉尔域(Boucot 等, 2001).

Johnson 等(1973)在讨论 Boucot 等(1969)的区划 成因时，在中-晚西根和埃姆斯期海陆分布图上使用 了一个通过西西伯利亚的“海路”将蒙古-鄂霍次克与 乌拉尔链接起来. Hou 等(1990)认为阿尔泰-萨彦地区 腕足动物群与乌拉尔的较亲近, 亦赞成海路成因. Boucot 等(2001)在具有现代含义的构造古地理图上 绘出古生物地理区分布图, 但尚未见详细说明.

\section{2 古生物地理区划}

中亚地区早泥盆世腕足动物较为丰富, 13 个化 石产地(图 1(a)) 共含有 235 属. 仅出现在一个化石产 地的有 97 属, 占 $40 \%$ 以上. 其中, 不乏土著属, 如: 小兴安岭的 Sinostrophia，赤塔的 Molongella，东乌旗 的 Aldanispirifer，东准噶尔的 Xinjiangospirifer，巴尔 喀什的 Mauispirifer，戈尔诺阿尔泰的 Mongolella，谢 罗夫-别拉亚河的 Antirhynchonella 等.

中亚地区早泥盆世腕足动物可以分为两个区： 巴尔喀什-蒙古-鄂霍次克区和乌拉尔-南天山区．前 


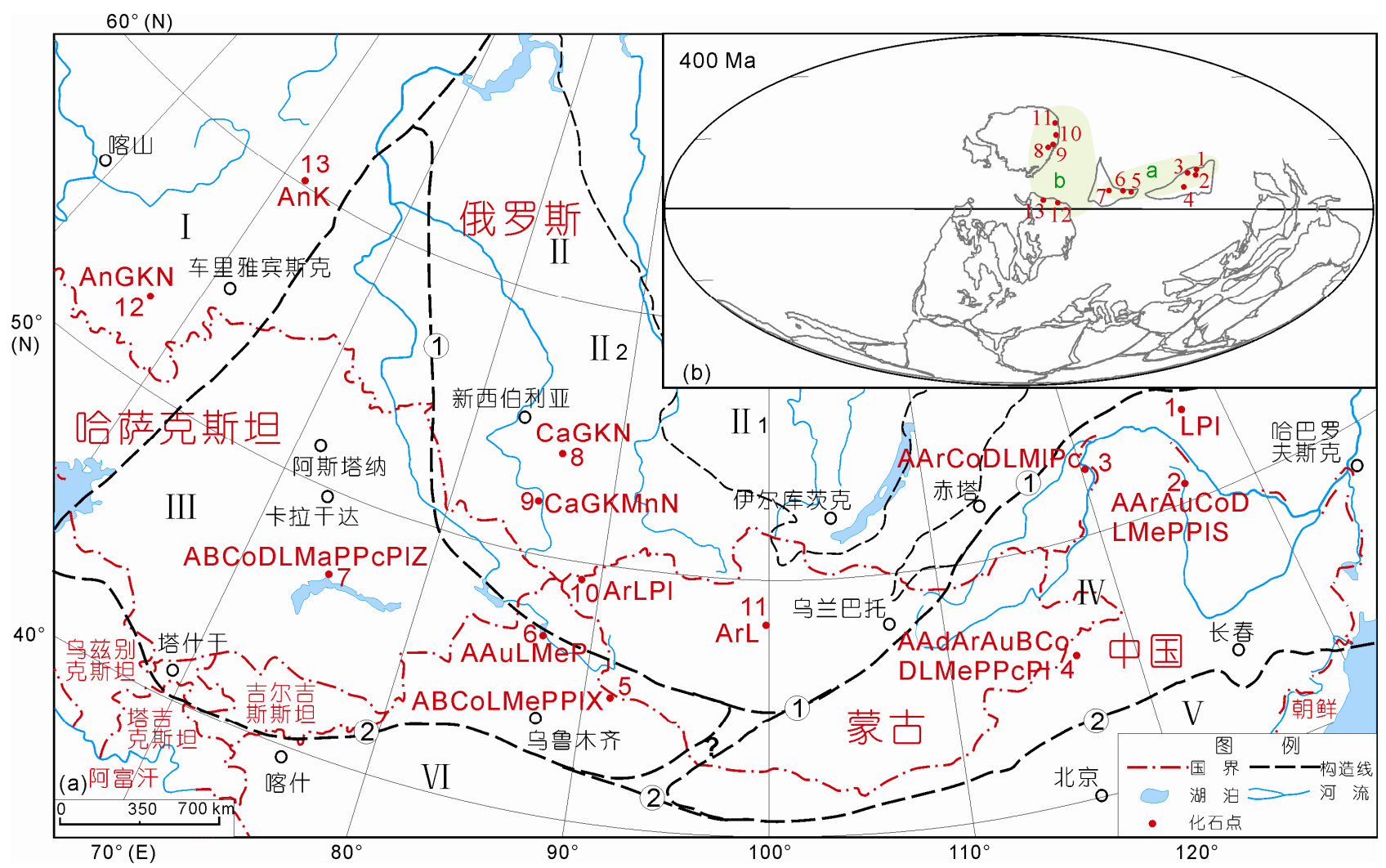

图 1 中亚地区早泥盆世腕足动物古生物地理与构造古地理协同演化

(a) 构造区划及化石产地分布图(构造轮廓根据 Zonenshain 等(1990), 王成文等(2008), Wang 等(2011)等资料编制). 主要构造单元：I -东欧板 块, II - 西伯利亚板块, II ${ }_{1}$-西伯利亚克拉通, $\mathrm{II}_{2}$-西伯利亚前晚古生代拼贴带, III-哈萨克斯坦板块, IV-佳-蒙地块, V-华北板块, VI-塔里木 地块. 主要缝合带: (1) 额尔齐斯-中蒙古-鄂霍次克缝合带, (2) 南天山-北山-西拉木伦缝合带(以下各图同). (b) 古生物地理区的构造古地理 位置图(构造古地理图根据 Boucot 等(2009)修改, 以下各图同). 化石产地编号与图 1(a)同, 古生物地理区编号: a-蒙古-鄂霍次克区, b-乌拉尔南天山区. 化石产地名称及资料来源: 1. 结尔河(Alekseeva 等, 2001); 2. 罕达汽(Hamada, 1971; 苏养正, 1980); 3. 马奇坎(Kul'kov, 2002$) ; 4$. 东乌旗(苏养正, 1976)； 5. 东准噶尔(张川等, 1983)；6. 西准噶尔(张川等, 1983); 7. 巴尔喀什(Sapelnikov 等, 1975; Modzalevskaya 等, 1978; Kaplun 等, 1991); 8. 库兹涅茨克盆地(Alekseeva, 1962; Alekseeva 等, 1970); 9. 戈尔诺阿尔泰(Kulkov, 1963; Gratsianova, 1967); 10. 蒙古阿尔 泰(Alekseeva, 1993; Oleneva, 2000; Alekseeva 等, 2001); 11. 塔里亚特(Alekseeva 等, 1981; Alekseeva 等, 2001); 12. 别拉亚河(Tjazheva 等, 1976); 13. 谢罗夫(Khodalevich, 1951). 特征属代号: $\mathrm{A}=$ Acrospirifer, $\mathrm{Ad}=$ Aldanispirifer, $\mathrm{Ae}=$ Alekseevaella, $\mathrm{An}=$ Antirhynchonella, $\mathrm{B}=$ Barrandella, $\mathrm{Ar}=$ Areostrophia, $\mathrm{Au}=$ Aulacella, $\mathrm{B}=$ Brachyspirifer, $\mathrm{Ca}=$ Carinatina $=$ Salairina, $\mathrm{Co}=$ Coelospira, $\mathrm{D}=$ Dalejina, $\mathrm{G}=$ Glossinulus $($ Glossinotoechia $), \mathrm{K}=$ Karpinskia, $\mathrm{L}=$ Leptostrophia=Rhytistrophia, $\mathrm{Ma}=$ Mauispirifer, $\mathrm{Me}=$ Megastrophia, $\mathrm{Ml}=$ Molongella, $\mathrm{Mn}=$ Mongolella, $\mathrm{N}=$ Nikiforovaena, $\mathrm{Pa}=$ Paraspirifer, $\mathrm{Pc}=$ Protochonetes, $\mathrm{Pl}=$ Protoleptostrophia=Tastaria, $\mathrm{S}=$ Sinostrophia, $\mathrm{X}=$ Xinjiangospirifer, $\mathrm{Z}=\mathrm{Zdimir}$

者包括巴尔喀什、东、西准噶尔、东乌旗、赤塔马奇 坎、小兴安岭罕达汽、结尔河等地区. 这一地区较为 特征的属为: Acrospirifer, Areostrophia, Aulacella, Brachyspirifer, Coelospira, Dalejina, Megastrophia, Paraspirifer, Protochonetes 等. 后者包括谢罗夫、别 拉亚河、库兹涅茨克盆地、戈尔诺阿尔泰、蒙古阿尔 泰以及塔里亚特等地区. 这一地区较为特征的属为: Glossinulus (Glossinotoechia), Karpinskia, Nikiforovaena 等.

巴尔喀什腕足动物群与准噶尔-蒙古-鄂霍次克
地区的腕足动物群十分密切, 含有较多的相同属, 如: Acrospirifer, Brachyspirifer, Coelospira, Dalejina, Euryspirifer, Leptaena, Leptaenopyxis, Lissatrypa, Paraspirifer, Plectodonia, Protochonetes, Rotundostrophia, Schuchertella 等. 尤其是 Coelospira 和 Paraspirifer 等是准噶尔-蒙古-鄂霍次克地区常见的 特征属, 同时未见有 Glossinulus (Glossinotoechia), Karpinskia, Nikiforovaena 等乌拉尔-南天山区特征属 的出现. 巴尔喀什与准噶尔-蒙古-鄂霍次克地区腕足 动物群应该同属于一个生物地理区. 巴尔喀什腕足 
动物群含有的 Altajella, Anastrophia, Clorinda, Dicoelosia, Machaeraria, Maoristrophia, Meristella, Multispiriter, Resserella, Sieberella, Strophodonta, Tastaria等亦常见于乌拉尔-南天山区，表现出一些过 渡色彩.

阿尔泰-萨彦腕足动物群与巴尔喀什-蒙古-鄂霍 次克的比较, 缺少后者大量的特征属, 如:Acrospirifer, Areostrophia, Aulacella, Brachyspirifer, Coelospira, Dalejina, Megastrophia, Paraspirifer, Protochonetes 等. 而含有乌拉尔区的特征属 Glossinulus, Karpinskia, Nikiforovaena 等, 尤其是 Karpinskia 的出现更为醒目. 应该属于乌拉尔-南天山区. 阿尔泰-萨彦地区的一些 常见属, 如: Altajella, Anastrophia, Clorinda, Clorinda, Clorindina, Dalejodiscus, Dicoelosia, Emanuella, Eospirifer, Gypidula, Ivdelinia, Machaeraria, Resserella, Sieberella, Spirigerina 等, 亦见于巴尔喀什. 阿尔泰萨彦地区腕足动物群与巴尔喀什的亦存在较为密切 关系.

\section{3 早泥盆世腕足动物古生物地理与构造古地理 的协同演化}

早泥盆世西伯利亚板块位于北纬中-低纬度带, 东欧板块东部位于赤道带(Scotese 等, 1990; Boucot 等, 2009). 西伯利亚板块自中生代以来顺时针旋转 $180^{\circ}$ (Zonenshain 等, 1990; Zorin 等, 1995; Gordienko, 2006). 如此, 现今阿尔泰-萨彦腕足动物群在早泥盆 世则处于西伯利亚板块东缘大陆边缘, 亦即乌拉尔 洋的北缘. 早泥盆世西伯利亚东缘、东欧板块北缘乃 至哈萨克斯坦板块的西缘均属于乌拉尔-南天山洋构 造域, 发育了乌拉尔-南天山腕足动物群, 形成了乌 拉尔-南天山生物地理区(图 1(b)).

早泥盆世，哈萨克斯坦板块、佳-蒙地块均位于 北纬低纬度带上(Scotese 等, 1990; Boucot 等, 2009). 哈萨克斯坦板块东北缘和佳-蒙地块的北缘属于额尔 齐斯-中蒙古-鄂霍次克洋构造域, 发育了额尔齐斯中蒙古-鄂霍次克腕足动物群, 形成了巴尔喀什-蒙古鄂霍次克生物地理区(图 1(b)).

尽管巴尔喀什腕足动物群属于巴尔喀什-蒙古鄂霍次克区, 但其与乌拉尔-南天山区亦有密切联系, 是由于: 在构造古地理位置上, 西伯利亚板块、哈萨 克斯坦板块、佳-蒙地块从西到东依次排列, 哈萨克斯 坦板块处于中间位置.

\section{3 早石炭世(Tournaisian-Serpukhovian)腕 足动物古生物地理与构造古地理的协同演化}

\section{1 古生物地理区划的研究现状}

早石炭世腕足动物群主要分布在西伯利亚板块 南缘增生带(库兹涅茨克盆地、矿山阿尔泰、乌里雅 苏台), 佳-蒙地块(马拉雅库林达、吉中、密山), 哈萨 克斯坦板块(阿斯塔纳、波罗霍洛山、甘草湖) 等地 区(图 2(a)).

杨式溥(1990) 将中亚地区早石炭世腕足动物群 划归北方大区，又区分为西伯利亚区的库兹涅茨克黑龙江亚区、阿尔泰-兴安岭亚区和哈萨克斯坦-内蒙 古区的哈萨克斯坦亚区、北天山-敖汉旗亚区. 张梓歆 等(1996)将中亚地区早石炭世腕足动物群划分为：哈 萨克斯坦-西伯利亚域的西伯利亚省库兹涅茨-阿尔 泰亚省和维尔霍扬亚省, 哈萨克斯坦-蒙古-兴安省哈 萨克斯坦-准噶尔亚省、内蒙古-兴安亚省、吉尔吉斯北天山亚省、吉林-日本亚省.

尽管所使用的区划单位术语有别，以上两种方 案差别不大. 主要体现为地理区自北而南的带状分布, 以及强调了 Gigantoproductini 和 Syringothyrididae 在 区划中的标志作用. 总的看划分过细，有些亚区、亚 省可能仅相当于生物演化中心.

\section{2 古生物地理区划}

中亚地区 11 个化石产地共含有腕足动物化石 136 属. 十分常见的属有：Antiquatonia, Avonia, Brachythyris, Dictyoclostus, Rhipidomella, Schizophoria, Schuchertella, Spirifer, Syringothyris 等.

早石炭世腕足动物分布两分性明显, 从库兹涅 茨克到赤塔一线, 是以 Rotaia, Rugosochonetes, Tolmatchoffia, Verkhotomia 等属为特征, 本文拟命名 为蒙古-鄂霍次克区，属于北方生物地理大区.从阿 斯塔纳到密山一线, 是以 Buxtonia, Gigantoproductus, Krotovia, Productus, Pugilus 等属为特征，本文拟命 名为乌拉尔-西拉木伦区.

从通常人们关注的 Gigantoproductini 和 Syringothyrididae 来看, Gigantoproductini 的分子在本区仅 见有 Gigantoproductus，其分布仅限于乌拉尔-西拉木 伦区，并且是一个非常繁盛的分子. Syringothyrididae 的分子在本区见有 Pseudosyrinx, Septosyringothyris, Syringothyris, Verkhotomia 等 4 属, 其中 Verkhotomia 


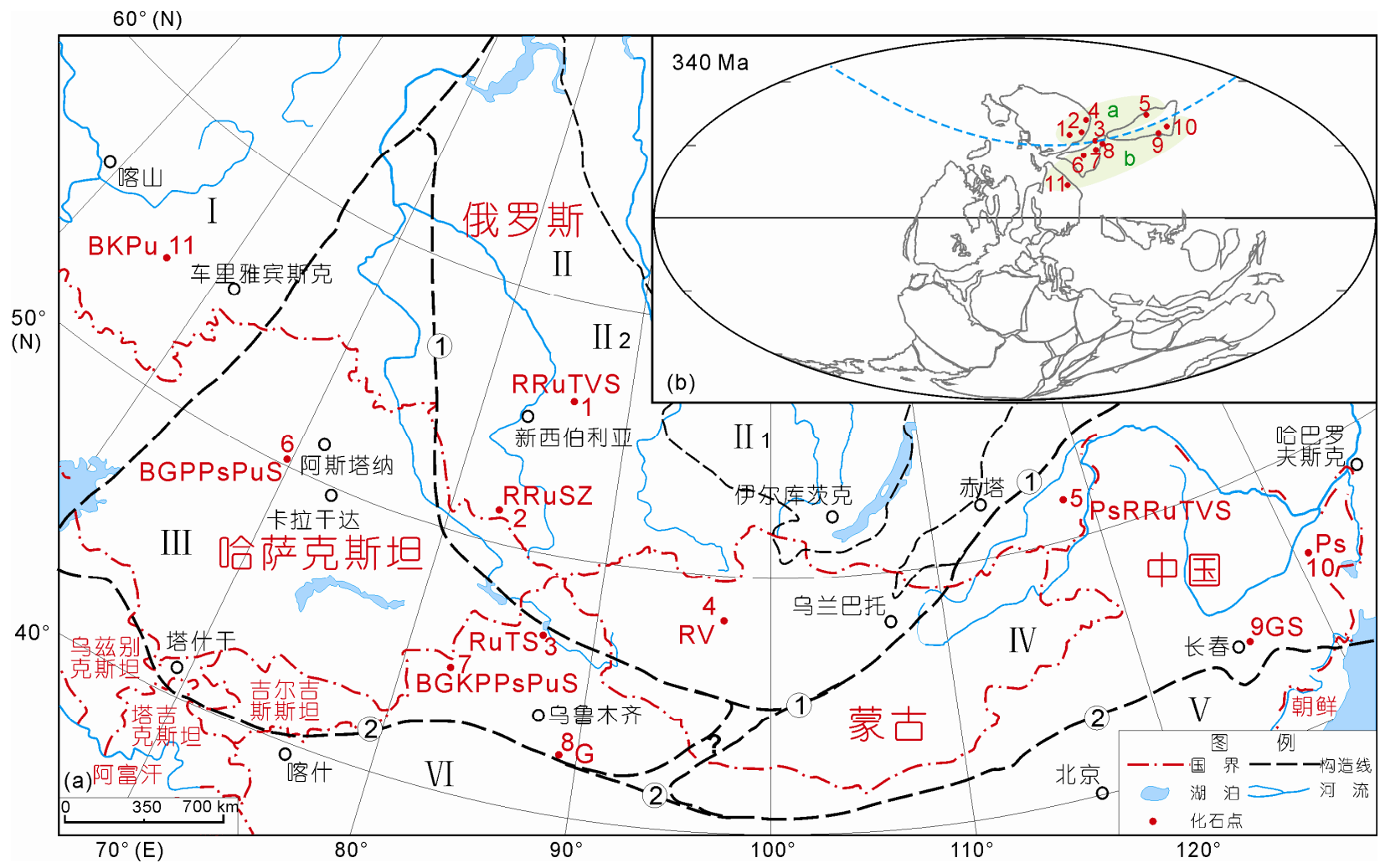

图 2 中亚地区早石炭世腕足动物古生物地理与构造古地理协同演化

(a) 同图 1. (b) 同图 1, 除 $\mathrm{a}$ 为蒙古-鄂霍次克区; $\mathrm{b}$ 为乌拉尔-西拉木伦区. 化石产地名称及资料来源: 1. 库兹涅茨克盆地(Sarytcheva等, 1963); 2. 矿山阿尔泰(Gretchishnikova, 1966); 3. 西准噶尔(张川等, 1983); 4. 乌里雅苏台(杨式溥, 1990); 5. 马拉雅库林达(Kotlyar, 2002); 6. 阿斯塔 纳(Litvinovich, 1962); 7. 博罗霍洛山(杨式溥, 1964); 8. 甘草湖(Chen 等, 2000); 9. 吉中(谷峰, 1986; 刘发, 1988); 10. 密山(苏养正等, 1987); 11. 斯捷尔利塔马克(Nalivkin, 1979). 特征属代号: B=Buxtonia, $\mathrm{G}=$ Gigantoproductus, $\mathrm{K}=$ Krotovia, $\mathrm{P}=$ Productus, $\mathrm{Ps}=$ Pseudosyrinx, $\mathrm{Pu}=$ Pugilus, $\mathrm{R}=$ Rotaia, $\mathrm{Ru}=$ Rugosochonetes, $\mathrm{T}=$ Tolmatchoffia, $\mathrm{V}=$ Verkhotomia, $\mathrm{S}=$ Syringothyris

在蒙古-鄂霍次克区十分常见，在乌拉尔-西拉木伦区 缺失，但其在特提斯大区的北美中部乃至阿瑟拜疆 等地区亦见其踪迹; Septosyringothyris 是一个两极分 布的分子，不但见于蒙古-鄂霍次克区，亦见于智利; Pseudosyrinx 在乌拉尔-西拉木伦区最为常见, 在冈瓦 纳大区的聂拉木-定日、新南威尔士、智利亦有所见; Syringothyris 在早石炭世是个世界性分布分子，其不 但在北方和冈瓦纳大区常见, 在特提斯大区亦是一 个常见分子. 所以, 从这两个科(族) 的分子分布情 况来看, Gigantoproductus 的古生物地理意义更为重 要. 将乌拉尔-西拉木伦区归入北方生物地理大区显 然不甚合理; 将北方生物地理大区限定在蒙古-鄂霍 次克区之内, 大量的 Gigantoproductus 出现, 则归入 特提斯大区可能更为恰当.

概括地说, 早石炭世腕足动物古生物地理出现 了较大的变化. 最重要的是生物地理区出现了更为
明显的自北而南的分带现象, 以及北方生物地理大 区的出现.

\section{3 腕足动物古生物地理与构造古地理的协同演化}

早石炭世, 西伯利亚板块、哈萨克斯坦板块北 缘、佳-蒙地块处于中-高纬度带, 东欧板块等亦相对 北移 (Scotese 等, 1990; 陈旭等, 2001; Boucot 等, 2009). 并且几个板块(地块) 相对靠拢, 在其北形成 了半封闭的蒙古-鄂霍次克洋构造域, 在蒙古-鄂霍次 克洋的南缘, 即西伯利亚板块的东缘、哈萨克斯坦板 块北缘、佳-蒙地块的北缘, 发育了蒙古-鄂霍次克腕 足动物群, 形成了蒙古-鄂霍次克生物地理区. 在东 欧板块东北缘、哈萨克斯坦板块大部分地区、佳-蒙 地块的南缘形成了乌拉尔-西拉木伦洋构造域, 发育 了乌拉尔-西拉木伦腕足动物群, 形成了乌拉尔-西拉 木伦生物地理区(图 2(b)). 
早石炭世北方生物地理大区的轮廓已经十分明 显(图 2(b)), 自此, 对腕足动物来说, 总体上按纬度 分带的北方、特提斯、冈瓦纳生物地理大区基本确定 下来.

\section{4 晚石炭世(Bashkirian-Gzhelian)腕足动 物古生物地理与构造古地理的协同演化}

\section{1 古生物地理区划的研究现状}

Ivanova 等(1979)在讨论莫斯科期全球腕足动物 古生物地理分区时, 将中亚地区哈萨克斯坦-赤塔一 线置于北亚大区, 乌拉尔-南天山置于西欧亚大区乌 拉尔区，内蒙-延吉一线置于西欧亚大区南亚区. 笔 者(王成文，1994a) 曾将全球晚石炭世腕足动物古生
物地理分为冈瓦纳、古地中海、北极三个大区，中亚 地区的北部置于北极大区，南部置于古地中海大区 的欧洲-华夏区。笔者(王成文，1996; 王成文等， 1998a; Wang 等, 2008) 亦曾论及此时期北方生物地 理大区的一些特征分子.

有关中亚地区晚石炭世腕足动物古生物地理区 划讨论较少, 这可能与人们常认为晚石炭世腕足动 物地理区区分不明显有关, 其实不然.

\section{2 古生物地理区划}

目前，搜集到的中亚地区腕足动物群主要化石 产地有 10 个, 涵盖了东欧板块、哈萨克斯坦板块、 佳-蒙地块、华北板块和塔里木地块等构造单元(图 3(a))，共含腕足动物 133 属. 最为明显的特征之一是 大量的二叠纪北方大区的凉水分子在此时已经出现,

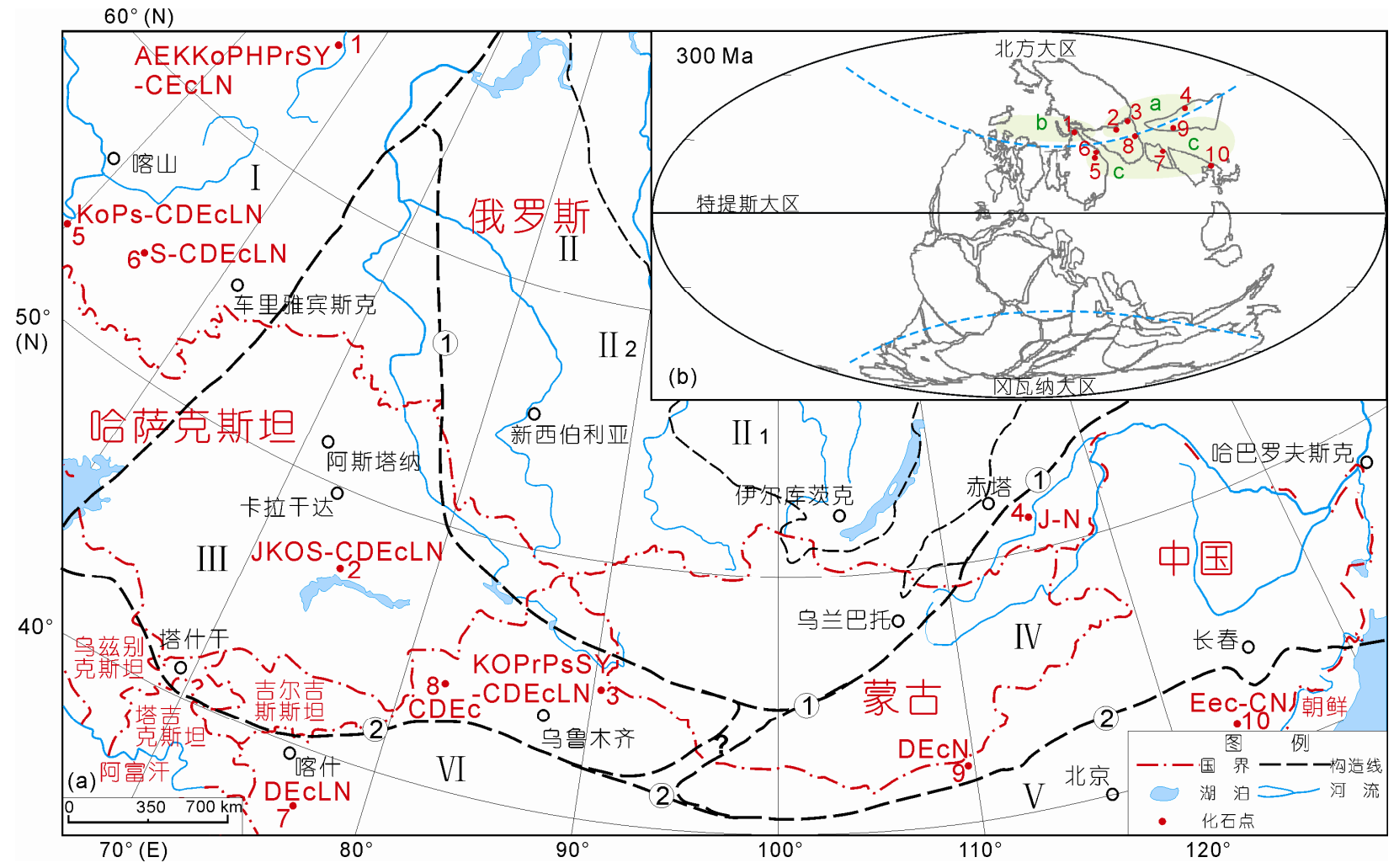

图 3 中亚地区晚石炭世腕足动物古生物地理与构造古地理协同演化

(a) 同图 1. (b) 同图 1, 除 $\mathrm{a}$ 为蒙古-鄂霍次克区, $\mathrm{b}$ 为巴伦支区, $\mathrm{c}$ 为欧洲-华夏区. 化石产地名称及资料来源: 1. 伯朝拉 (Kalashnikov, 1980); 2. 北滨巴尔喀什(Sarytcheva 等, 1968); 3. 石钱滩(王成文等, 1998b); 4. 赤塔(Kotlyar, 2002); 5. 萨马拉(Prokofev, 1975); 6. 巴什基尔(Mironova, 1967); 7. 西昆仑山(Chen 等, 2000); 8. 博罗霍洛山(杨式溥, 1964); 9. 本巴图(李莉等, 1980a); 10. 本溪(李莉等, 1980a; 刘发, 1987). 特征属代 号: A=Attenuatella, E=Elivina, J=Jakutoproductus, $\mathrm{K}=$ Kitakamithyris, Ko=Kochiproductus, $\mathrm{O}=$ Orulgania, $\mathrm{P}=$ Paeckelmanella, $\mathrm{H}=$ Horridonia, $\mathrm{Pr}=$ Praehorridonia, $\mathrm{Ps}=$ Pseudosyrinx, S=Spiriferellina, Y=Yakovlevia. 常见属代号: C=Choristites, D=Dictyoclostus, Ec=Echinoconchus, $\mathrm{L}=$ Linoproductus, $\mathrm{N}=$ Neospirifer 
并占据伯朝拉-巴尔喀什-石钱滩-赤塔一线. 这些分子 有: Attenuatella, Elivina, Jakutoproductus, Kitakamithyris, Kochiproductus, Orulgania, Paeckelmanella, Pleurohorridonia, Praehorridonia, Pseudosyrinx, Yakovlevia 等. 这些凉水型分子亦常见于科累马、泰梅尔以及加 拿大育空等地区. 所以, 伯朝拉-巴尔喀什-石钱滩赤塔一线应该为北方生物地理大区. 在伯朝拉-巴 尔喀什-石钱滩-赤塔等化石产地, 亦常见有特提斯大 区的常见繁盛分子, 如: Choristites, Dictyoclostus, Echinoconchus, Linoproductus, Neospirifer 等, 这似乎 给伯朝拉-巴尔喀什-石钱滩-赤塔一线的腕足动物群 增加了一些特提斯大区的色彩. 其实, 不仅在中亚地 区如此, 在北方生物地理大区的其他地区, 如科累马楚科奇、泰梅尔等地区亦是如此. 这一现象反映的可 能是北方生物地理大区与特提斯生物地理大区腕足 动物演化方面的亲缘关系. 但无论如何, 大量的凉水 分子的出现为认定伯朝拉-巴尔喀什-石钱滩-赤塔一 线属于北方生物地理大区提供了明显的标志.

北方生物地理大区亦明显分为两个区. 巴尔喀 什-石钱滩-赤塔腕足动物群中的 Zaissania, Jilinomartinia, Beecheria, Flexaria, Marginifera, Wellerella 等属末见于伯朝拉腕足动物群, 而伯朝拉腕足动物 群中的 Alexania, Attenuatella, Elivina, Paeckelmanella, Parachoristites, Plicatiferina, Horridonia, Spinomarginifera, Spirifer, Strophalosia, Thuleproductus, Torquistia 等属亦未见于巴尔喀什-石钱滩-赤塔腕足动物群. 笔 者拟将巴尔喀什-石钱滩-赤塔腕足动物群分布区命 名为蒙古-鄂霍次克生物地理区, 将伯朝拉-泰梅尔科累马-楚科奇地区腕足动物群分布区命名为巴伦支 生物地理区.

佳-蒙地块的南缘、哈萨克斯坦板块大部分以及 东欧板块的绝大部分区域, 往往缺少北方生物大区 的凉水分子, 个别地区仅有零星出现. 所以这一地区 应该属于特提斯生物地理大区欧洲-华夏区(王成文, 1994a).

\section{3 腕足动物古生物地理与构造古地理的协同演化}

晚石炭世，北美、东欧、西伯利亚板块等持续的 北移, 西伯利亚板块已经处于较高纬度带上, 哈萨克 斯坦板块可能已经与西伯利亚板块拼贴(Scotese 等, 1990; 陈旭等, 2001; Boucot 等, 2009). 佳-蒙地块古 纬度似乎变化不大, 但其可能与西伯利亚-哈萨克斯 坦板块位置较近. 如此, 佳-蒙地块北缘、西伯利亚板
块东南缘(原哈萨克斯坦板块西北缘)、东欧板块北缘 可能处于同一纬度带上, 统属于北方生物地理大区 (图 3(b)).

西伯利亚板块(含哈萨克斯坦板块) 东北缘与佳蒙地块北缘处于蒙古-鄂霍次克洋构造域, 发育了巴 尔喀什-石钱滩-赤塔腕足动物群, 形成了蒙古-鄂霍 次克生物地理区. 西伯利亚板块西南缘与东欧板块 的北缘处于巴伦支洋构造域, 发育了伯朝拉-泰梅尔科累马-楚科奇腕足动物群, 形成了巴伦支生物地理 区(图 3(b)).

东欧板块、西伯利亚板块南部(原哈萨克斯坦板 块大部)、塔里木地块、华北板块以及佳-蒙地块南缘 处于古特提斯洋北缘构造域, 发育了东欧-塔里木-华 北腕足动物群, 形成了欧洲-华夏生物地理区.

\section{5 早二叠世(Asselian-Artinskian)腕足动物 古生物地理与构造古地理的协同演化}

\section{1 古生物地理区划的研究现状}

Stehli 等(1971)和 Stehli(1973)提出了凉水型北极 大区的概念, 但将伯朝拉地区腕足动物群划归特提 斯大区. 笔者(王成文, 1994a) 在讨论全球晚石炭世 腕足动物古生物地理区划时, 大致以 $45^{\circ} \mathrm{N}$ 为界将中 亚地区阿瑟尔期腕足动物群古生物地理区划归为北 极大区 (相当本文的北方大区)和古地中海大区 (相当 本文的特提斯大区). 尚庆华等(1997)将中乌拉尔、北 乌拉尔划归北方大区乌拉尔-蒙古区; 延吉、平顶山地 区划归特提斯大区华北区; 将喀什、柯坪等地区划归 特提斯大区西特提斯区.

\section{2 古生物地理区划}

中亚地区北部早二叠世腕足动物群仅见于东欧 板块伯朝拉地区. 在哈萨克斯坦板块仅见于巴尔喀 什湖以北地区. 在佳-蒙地块南缘较为发育, 以平顶 山地区最具代表性. 同时, 在中亚造山带南部边界地 区, 从延吉的山秀岭、塔里木盆地北缘阿克苏到喀什 以及南费尔干盆地等地区均有发育.

七个化石点共含腕足动物 156 属, 可见这一时期 的腕足动物群属的分异度较高. 不仅如此, 在这些化 石产地还有一些十分常见的属, 如: Brachythyrina, Cancrinella, Chaoiella, Choristites, Hustedia, Linoproductus, Martinia, Neospirifer, Stenoscisma 等, 常给 
人一种区分不明显的假象. 但是, 经过认真篮查、比 对，北方生物地理大区和特提斯生物地理大区的区 分还是很明显的.

伯朝拉地区和巴尔喀什北等地区明显属于北方 生物地理大区，它们含有大量的北方生物地理大区 的特征属, 如: Attenuatella, Calliprotonia, Horridonia, Kitakamithyris, Lissochonetes, Orulgania, Paeckelmanella, Pseudomarginifera, Pseudosyringothyris, Spiriferellina, Tomiopsis, Yakovlevia, Zaissania 等. 伯 朝拉地区和巴尔喀什北等地区又有明显的不同. 首 先, 伯朝拉地区腕足动物群属分异度明显高于巴尔 喀什地区，在伯朝拉地区描述的腕足动物共有 73 属 之多, 而巴尔喀什地区仅出现有 30 属. 其次, 发育在 巴尔喀什地区的 Zaissania, Peniculauris, Orulgania, Kitakamithyris, Heteralosia, Costiferina, Beecheria 等 属末见于伯朝拉地区，伯朝拉地区发育的 Arctitreta, Bailliena, Cyrtella, Elivina, Fredericksia, Horridonia, Kochiproductus, Paeckelmanella, Pseudomarginifera, Pseudosyringothyris, Thuleproductus, Uraloproductus, Yakovlevia 等大量的属末见于巴尔喀什地区. 笔者仍 然倾向将这一时期北方生物地理大区分为蒙古-鄂霍 次克生物地理区和巴伦支生物地理区. 只是蒙古-鄂 霍次克生物地理区的腕足动物群有些萎缩, 而巴伦 支生物地理区明显的扩大. 此时期的巴伦支生物地 理区不仅含伯朝拉地区，同时还包括泰梅尔、楚科 奇、斯瓦尔巴乃至北美的育空地区. 后者明显超出本 文的范畴，在此不作进一步讨论.

从南费尔干盆地到延吉一线的这些腕足动物群 属于特提斯大区, 所含特征属为: Alexania, Enteletes, Hemiptychina, Jursania, Marginifera, Notothyris, Uncinunellina 等, 并且几乎看不到凉水分子的踪迹.

将南费尔干盆地-喀什-阿克苏地区腕足动物群 与平顶山-延吉地区的比较, 不难发现, 两区存在许 多共同的常见属, 如: Alexania, Brachythyrina, Choristites, Enteletes, Hustedia, Jursania, Linoproductus, Marginifera, Martinia, Neospirifer, Notothyris, Plicatifera, Reticulatia, Stenoscisma, Uncinunellina 等. 这似乎说 明，两地区差异不大. 本文仍然倾向于将南费尔干盆 地-延吉地区腕足动物群归入特提斯大区的欧洲-华 夏区.

在此附带说明, 按照国际地质年代表, Kungurian 应该属于早二叠世. 但是, 中亚地区腕足动物群的重
大转变发生在 Kungurian, 著名的哲斯腕足动物群时 限为 Kungurian-Capitanian. 为了便于讨论, 本文将 Kungurian 的腕足动物群置于中二叠世部分讨论.

\section{3 腕足动物古生物地理与构造古地理的协同演化}

巴伦支生物地理区的明显扩大是由于随着几个 大陆板块的北移，西伯利亚板块，北美板块北部、东 欧板块北部均已经进入高纬度区(图 4(b)).

佳-蒙地块、塔里木地块等北移幅度较小, 西伯 利亚板块巴尔喀什地区(原属哈萨克斯坦板块) 与东 欧板块的伯朝拉地区相近并大致处于同一纬度带上， 发育了北方生物地理大区腕足动物群(图 4(b)). 蒙古鄂霍次克构造域变化不大, 蒙古-鄂霍次克生物地理 区的腕足动物群略有萎缩.

佳-蒙地块、塔里木地块等仍然处于中-低纬度带 上, 发育了特提斯大区的腕足动物群, 形成欧洲-华 夏生物地理区. 在早二叠世, 佳-蒙地块、华北板块西 北缘、塔里木地块、西伯利亚-哈萨克斯坦板块、东 欧板块之间, 虽然均较为接近, 但可能并未拼合, 海 洋相通，在中亚地区的两个生物大区中含有较多的 相同的常见分子(图 4(a)).

\section{6 中二叠世(Kungurian-Capitanian)腕足动 物古生物地理与构造古地理的协同演化}

\section{1 古生物地理区划的研究现状}

中亚地区中二叠世腕足动物相对集中分布于乌 拉尔山西坡伯朝拉地区和佳-蒙地块南缘的西起甘肃 北山经内蒙古过吉林和黑龙江省南部直到俄罗斯远 东等地区. 后者亦即著名的哲斯腕足动物群分布区. 其它地区亦有零星出现, 化石单调, 对于生物地理区 讨论意义不大.

人们多论及哲斯腕足动物群古生物地理特征, 通常认为其既含有北方生物地理大区的凉水型分子 又含有特提斯生物地理大区的暖水型分子, 故称之 为混生的腕足动物群(Wang 等, 2012). 既然是“混生”, 那么不论划归北方大区还是划归特提斯大区似乎均 在情理之中. 因此，各家生物地理区划分方案分歧较 大: 划归特提斯大区(Grunt, 1998; Shi, 1998; Shi 等, 2002); 划归北方大区(徐桂荣等，1988; 尚庆华等, 1997; 王成文等, 2003, 2008; Wang 等, 2012). 


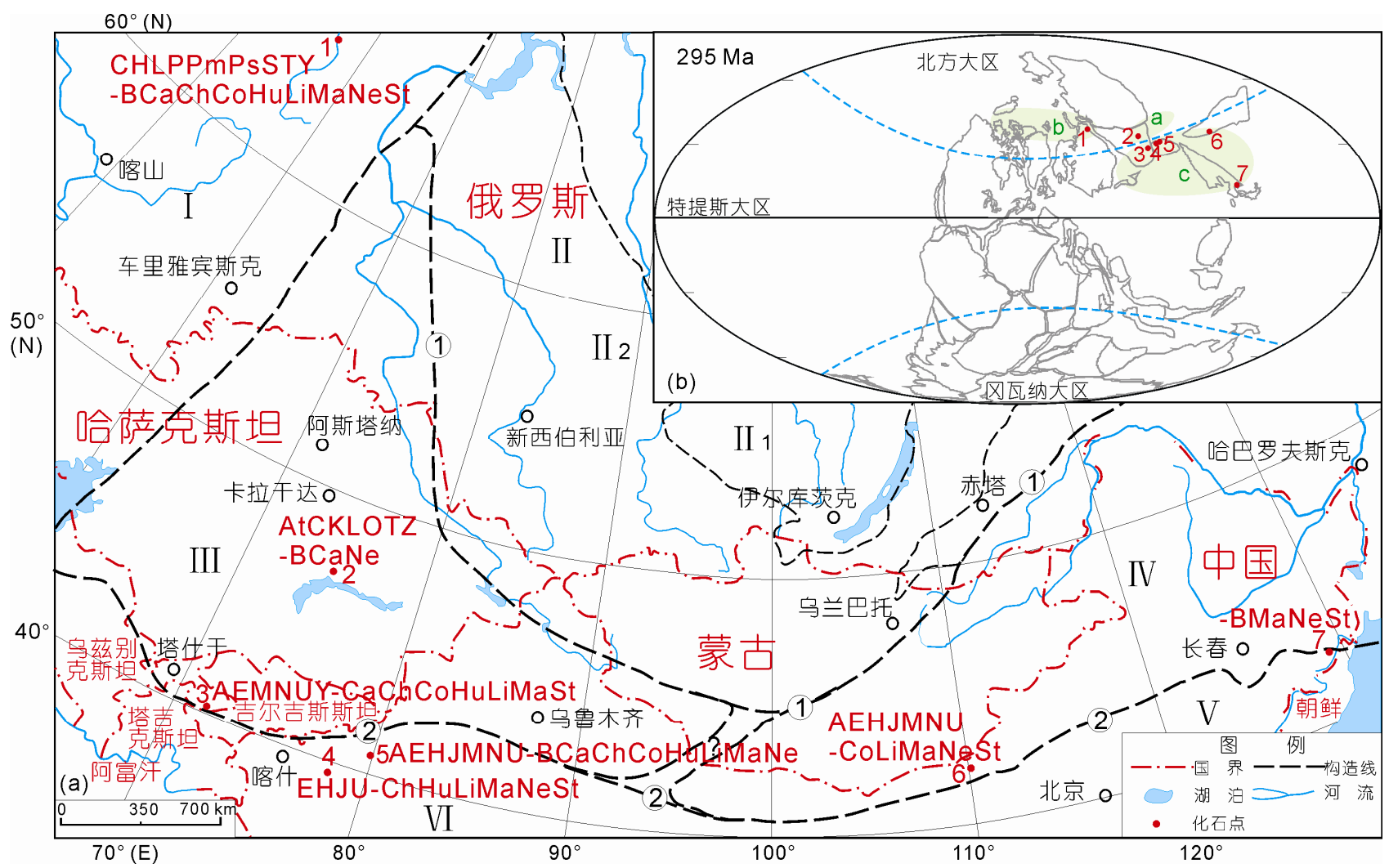

图 4 中亚地区早二叠世腕足动物古生物地理与构造古地理协同演化

(a) 同图 1. (b) 同图 1, 除 $\mathrm{a}$ 为蒙古-鄂霍次克区, $\mathrm{b}$ 为巴伦支区, $\mathrm{c}$ 为欧洲-华夏区. 化石产地名称及资料来源: 1. 伯朝拉 (Kalashnikov, 1980, 1993, 1998); 2. 巴尔喀什(Sarytcheva 等, 1968); 3. 南费尔干盆地(Volgin, 1960); 4. 乌尊布拉克(Chen, 2004); 5. 阿克苏(王成文等, $1998 b$ ); 6. 平顶山(赵泽国, 1965); 7. 延吉(李莉等, 1980b). 特征属代号: A=Alexania, At=Attenuatella, $\mathrm{C}=$ Calliprotonia, E=Enteletes, H=Hemiptychina, $\mathrm{Ho}=$ Horridonia, $\mathrm{J}=$ Jursania, $\mathrm{K}=$ Kitakamithyris, $\mathrm{L}=$ Lissochonetes, $\mathrm{M}=$ Marginifera, $\mathrm{N}=$ Notothyris, $\mathrm{O}=$ Orulgania, $\mathrm{P}=$ Paeckelmanella, $\mathrm{Pm}=$ Pseudomarginifera, $\mathrm{Ps}=$ Pseudosyringothyris, $\mathrm{S}=$ Spiriferellina, $\mathrm{T}=$ Tomiopsis, $\mathrm{U}=$ Uncinunellina, $\mathrm{Y}=$ Yakovlevia, Z=Zaissania. 常见属代号: $\mathrm{B}=$ Brachythyrina, $\mathrm{Ca}=$ Cancrinella, $\mathrm{Ch}=$ Chaoiella, $\mathrm{Co}=$ Choristites, $\mathrm{Hu}=$ Hustedia, $\mathrm{Li}=$ Linoproductus, $\mathrm{Ma}=$ Martinia, $\mathrm{Ne}=$ Neospirifer, $\mathrm{St}=$ Stenoscisma

\section{2 古生物地理区划}

无论是哲斯腕足动物群还是伯朝拉地区腕足动 物群均含有较多的北方大区凉水型属, 主要有: Alispiriferella, Anidanthus, Kitakamithyris, Kochiproductus, Licharewia, Paeckelmanella, Permospirifer, Pseudomarginifera=Megousia, Spiriferella, Tomiopsis, Yakovlevia 等. 其中, Kochiproductus, Pseudomarginifera=Megousia, Spiriferella, Yakovlevia 等属几乎在 主要化石点均有产出(图 5(a)). 两地区均应属于北方 生物地理大区.

关于哲斯腕足动物群古生物地理区的属性, 笔 者等(王成文等, 2003; Wang 等, 2008, 2012) 做过较 为详细的讨论, 在此摘其要点如下: 哲斯腕足动物群 中凉水型属、种多样性和种的个体丰度极高, 它们构 成了动物群的主体; 与北方生物地理大区俄罗斯欧
洲北部、斯瓦尔巴群岛、加拿大极区群岛等地同时期 腕足动物群十分相似; 亦未出现真正的 “暖水型”分 子. 哲斯腕足动物群是一个凉水型腕足动物群, 应划 归北方生物地理大区.

哲斯腕足动物群与伯朝拉地区腕足动物群较强 的相似性主要表现为: 两地区含有许多相同属, 尤其 相同的凉水型属, 如: Kochiproductus, Licharewia, Paeckelmanella, Permospirifer, Pseudomarginifera $=$ Megousia, Spiriferella, Timaniella, Yakovlevia 等. 但是, 两者之间亦存在一定的差异, 主要表现在: 伯朝拉地 区的一些属, 如: Horridonia, Arctochonetes, Cyrtella, Globiella, Grandaurispina, Svalbardia, Terrakea, Uraloproductus 等, 未见于哲斯动物群. 哲斯动物群中 的一些属, 如: Compresscproductus, Fallaxoproductus, Fusispirifer, Paramarginifera, Rhombospirifer 等, 未 


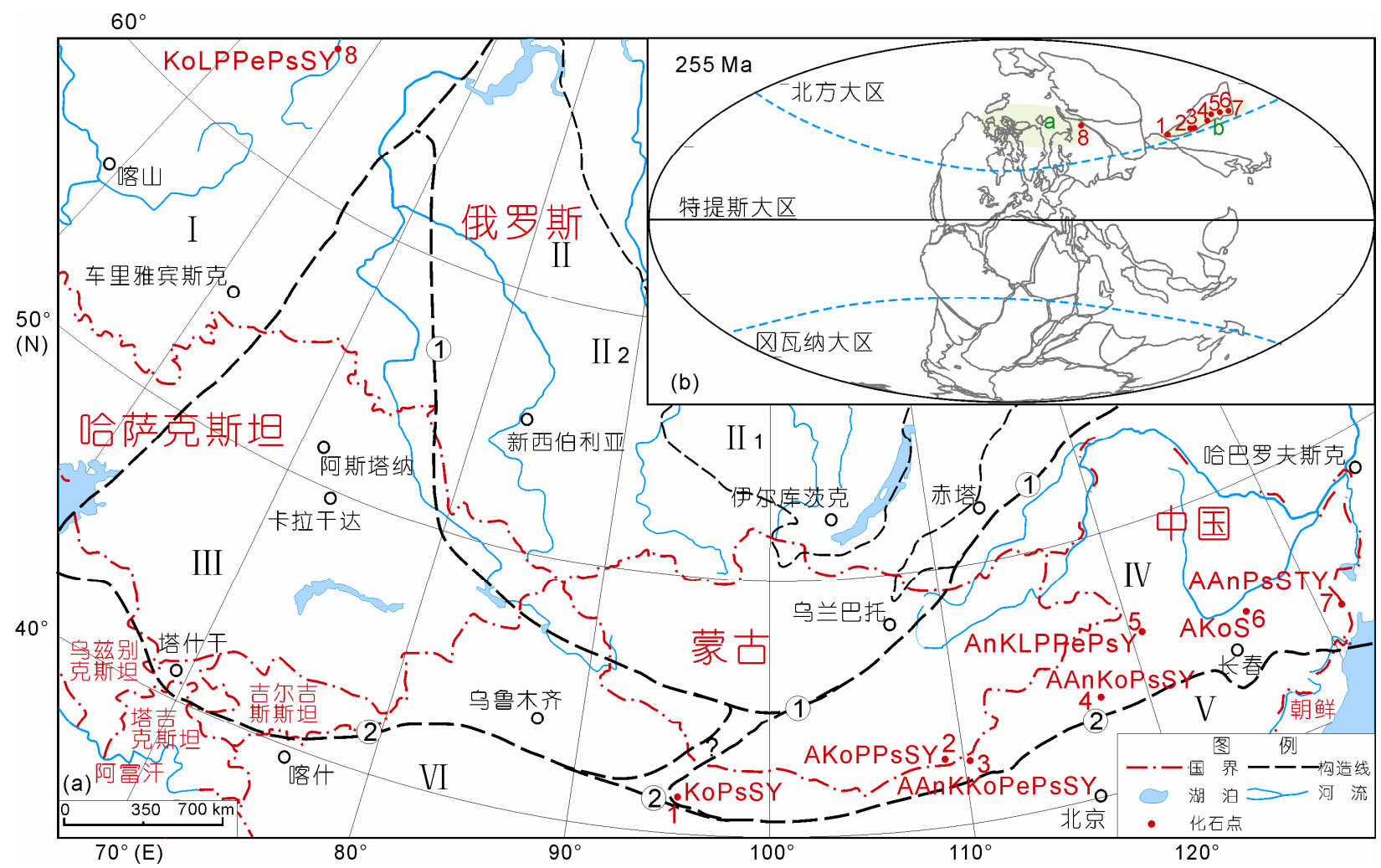

图 5 中亚地区中二叠世腕足动物古生物地理与构造古地理协同演化

(a) 同图 1. (b) 同图 1, 除 $\mathrm{a}$ 为巴伦支区, $\mathrm{b}$ 为内蒙古区. 化石产地名称及资料来源: 1. 北山(乌斯特利茨基, 1963); 2. 南蒙古(Pavlova等, 1991); 3. 哲斯(王成文等, 2003); 4. 西乌旗(王成文等, 2003); 5. 得伯斯(王成文等, 2003); 6. 五常(Tazawa 等, 2006); 7. 乌苏里斯克(Fredericks, 1925; Licharew 等, 1978); 8. 伯朝拉(Kalashnikov, 1980, 1993, 1998). 特征属代号: A=Alispiriferella, An=Anidanthus, K=Kitakamithyris, Ko= Kochiproductus, L=Licharewia, $\mathrm{P}=$ Paeckelmanella, $\mathrm{Pe}=$ Permospirifer, $\mathrm{Ps}=$ Pseudomarginifera=Megousia, $\mathrm{S}=$ Spiriferella, $\mathrm{T}=$ Tomiopsis, $\mathrm{Y}=$ Yakovlevia

见于伯朝拉地区. 鉴于以上差别, 加之哲斯腕足动物 群是一个含有 $75 \%$ 以上的土著种的土著动物群, 应 该自成一个生物地理区一内蒙古区(王成文等, 2003; Wang 等, 2012). 伯朝拉地区腕足动物群仍然属于巴 伦支生物地理区．内蒙古和巴伦支生物地理区皆属 于北方生物地理大区.

\section{3 腕足动物古生物地理与构造古地理的协同演化}

中二叠世, 随着北美、东欧、西伯利亚等板块持 续北移(Scotese 等, 1990; 陈旭等, 2001; Boucot 等, 2009)，巴伦支生物地理区的北方生物地理大区色彩 更为浓重.

随着佳-蒙地块快速北移, 佳-蒙地块西端可能与 塔里木地块以及华北板块西端拼合, 形成了西拉木 伦洋构造域(图 5(b)), 属于此构造域的佳-蒙地块南缘 发育了哲斯腕足动物群, 形成了内蒙古生物地理区
(Wang 等, 2012).

\section{7 结论}

（1）早泥盆世，西伯利亚板块东缘、东欧板块北 缘乃至哈萨克斯坦板块的西缘均属于乌拉尔-南天山 洋构造域, 发育了乌拉尔-南天山腕足动物群, 形成 了乌拉尔-南天山生物地理区. 哈萨克斯坦板块东北 缘和佳-蒙地块北缘属于额尔齐斯-中蒙古-鄂霍次克 洋构造域, 发育了额尔齐斯-中蒙古-鄂霍次克腕足动 物群, 形成了巴尔喀什-蒙古-鄂霍次克生物地理区.

(2) 早石炭世, 西伯利亚板块东缘、哈萨克斯坦 板块北缘、佳-蒙地块北缘属于蒙古-鄂霍次克洋构造 域, 发育了蒙古-鄂霍次克腕足动物群, 形成了蒙古鄂霍次克生物地理区. 东欧板块东北缘、哈萨克斯坦 板块大部分、佳-蒙地块南缘属于乌拉尔-西拉木伦洋 
构造域, 发育了乌拉尔-西拉木伦腕足动物群, 形成 了乌拉尔-西拉木伦生物地理区.

(3) 晚石炭世, 西伯利亚板块东北缘与佳-蒙地 块北缘属于蒙古-鄂霍次克洋构造域, 发育了巴尔喀 什-石钱滩-赤塔腕足动物群, 形成了蒙古-鄂霍次克 生物地理区. 西伯利亚板块西南缘与东欧板块西北 缘属于巴伦支洋构造域, 发育了伯朝拉-泰梅尔-科累 马腕足动物群, 形成了巴伦支生物地理区. 东欧板块 东北缘、西伯利亚板块南部、塔里木地块、华北板块 以及佳-蒙地块南缘处于古特提斯洋构造域, 发育了 东欧-塔里木-华北腕足动物群, 形成了欧洲-华夏生
物地理区.

（4）早二叠世，属于巴伦支洋构造域的东欧板块 北部等一些地区均已经进入高纬度区, 巴伦支生物 地理区明显扩大. 佳-蒙、塔里木等地块北移幅度较小, 北方生物大区蒙古-鄂霍次克生物地理区和特提斯大 区的欧洲-华夏生物地理区变化不大.

（5）中二叠世，随着佳-蒙地块快速北移，佳-蒙 地块西端可能与塔里木地块以及华北板块西端拼合, 形成了西拉木伦洋构造域, 属于此构造域的佳-蒙地 块南缘发育了哲斯腕足动物群, 形成了内蒙古生物 地理区.

\section{参考文献}

Boucot A J, 陈旭, Scotese C R, 等. 2009. 显生宙全球古气候重建. 北京: 科学出版社. 173

陈旭, 阮亦萍, Boucot, A J, 等. 2001. 中国古生代气候演变. 北京: 科学出版社. 325

成守德, 祁世军, 陈川, 等. 2009. 巴尔喀什-准噶尔构造单元划分及特征. 新疆地质, 27(增刊): 14-30

谷峰. 1986. 石炭-二叠纪腕足动物. 见: 吉林省地质矿产局, 编. 吉林省古生物图册. 长春: 林科学技术出版社. 210-255

李春昱, 王荣, 刘雪亚, 等. 1982. 亚洲大地构造图(1:800 万)说明书. 北京: 地图出版社. 49

李莉, 谷峰, 苏养正. 1980a. 石炭纪-二叠纪的腕足动物. 见: 沈阳地质矿产研究所, 编著. 东北地区古生物图册(一)古生代分册. 北京: 地质出版社. 327-428

李莉, 谷峰. 1980b. 吉林省延边地区晚石炭世腕足动物. 古生物学报, 19: 485-492

刘发. 1987. 辽宁本溪地区本溪组下部腕足类化石的发现及其意义. 长春地质学院学报, 17: 121-130, 154, pls.1-2

刘发. 1988. 吉林中部早石炭世杜内期的腕足动物化石. 长春地质学院学报, 18: 361-370

任纪舜, 王作勋, 陈丙蔚, 等. 2002. 从全球看中国大地构造一一国及邻区大地构造图简要说明. 北京: 地质出版社. 50

尚庆华, 金玉玕. 1997. 二叠纪腕足动物地理区系演化特征. 古生物学报, 73: 93-118

苏养正, 谷峰. 1987. 黑龙江省东部密山地区早石炭世北兴组腕足动物. 中国地质科学院沈阳地质矿产研究所所刊, 15: 145-155

苏养正. 1976. 寒武纪-泥盆纪的腕足动物. 见: 内蒙古自治区地质局, 东北地质科学研究所, 主编. 华北地区古生物图册 内蒙古分册(一) 古生代部分. 北京: 地质出版社. 159-227

苏养正. 1980. 寒武纪-泥盆纪的腕足动物. 见: 沈阳地质矿产研究所, 编著. 东北地区古生物图册(一). 古生代分册. 北京: 地质出版社. 294-327

王成文, 金巍, 张兴洲, 等. 2008. 东北及邻区大地构造属性的新认识. 地层学杂志, 32: 119-136

王成文, 孙跃武, 李宁, 等. 2009. 中国东北及邻区晚古生代地层分布规律的大地构造意义. 39: 1429-1437

王成文, 杨式溥. 1998a. 准噶尔盆地石钱滩腕足动物群中凉水分子的发现及意义. 地质学报, 72: 205-210, 图版 1

王成文, 杨式溥. 1998b. 新疆中部晚石炭世-早二叠世腕足动物及其生物地层学研究. 北京: 地质出版社. 156, pls.24

王成文, 张松梅. 2003. 哲斯腕足动物群. 北京: 地质出版社. 210, 图版 1-50

王成文. 1994a. 晚石炭世腕足动物古生物地理区. 吉林地质, (1): 14-23

王成文. 1994b. 晚石炭世腕足动物古生物地理区形成机制——环境控制论. 吉林地质, (2): 13-21

王成文. 1996. 晚石炭世腕足动物部分属的两极分布及其意义. 长春地质学院学报, 26: 125-130

王鸿祯, 杨式溥, 朱鸿, 等. 1990. 见: 王鸿祯, 杨森南, 刘本培, 等, 编. 中国及邻区构造古地理和生物古地理. 武汉: 中国地质大学出 版社. 35-86

王鸿祯. 1981. 从活动论观点论中国大地构造分区. 地球科学, 14: 42-66

王乃文. 1984. 青藏高原古生物地理与古板块构造的探讨. 中国地质科学院地质所所刊, 9: 1-23

乌斯特利茨基 B. 1963 . 甘肃西部北山地区二叠纪地层及动物群. 中华人民共和国地质部地质科学院专刊, 乙种 地层学古生物学, 5: 1-48 谢树成, 龚一鸣, 童金南, 等. 2006. 从古生物学到地球生物学的跨越. 科学通报, 51:2327-2336

徐桂荣, 杨伟平. 1988. 二叠纪. 见: 殷鸿福等, 主编. 中国古生物地理学. 武汉: 中国地质大学出版社. 176-197 
杨式溥. 1964. 新疆波罗霍洛山北坡下、中石炭统腕足动物及其地层意义. 北京: 科学出版社. 179, 图版 23

杨式溥. 1990. 中国及邻区早石炭世腕足动物生物地理分区. 见: 王鸿祯, 杨森南, 刘本培, 等, 编. 中国及邻区构造古地理和生物古地理. 北京: 中国地质大学出版. 317-335

殷鸿福, 谢树成, 童金南, 等. 2009. 谈地球生物学的重要意义. 古生物学报, 48: 293-301

殷鸿福等. 1988. 中国古生物地理学. 武汉: 中国地质大学出版社. 329

张川, 张风鸣, 张梓歆, 等. 1983. 腕足动物门. 见: 新疆地质局区域地质调查大队, 地质科学研究所, 新疆石油局地质调查处, 主编. 西 北地区古生物图册, 新疆维吾尔自治区分册(二) (古生代). 北京：地质出版社. 262-385, pls.86-145

张梓歆, 王宝瑜. 1996. 兴蒙-新疆北部及邻区早石炭世古生物地理区系. 新疆地质, 14: 37-47

赵泽国. 1965. 内蒙古中部晚石炭世的腕足类化石. 古生物学报, 13: 420-454, 图版 1-5

Alekseeva R E. 1962. Devonian atrypids from the Kuznetsk and Minussinsk basins and the eastern part of the northern Urals (in Russian). Moscow: Akad Nauk SSSR Siberian Div Inst Geol Geophys, 196, pls.11-12

Alekseeva R E. 1993. Biostratigraphy of Devonian of Mongolia (in Russian). Moscow: Scientific Press. 123

Alekseeva R E, Afanasjeva G A, Schischkina G R. 2001. Lower and Middle Devonian branchiopods of the Far East of Russia and Mongolia: Strophomenids and Chonetids (in Russian). Moscow: Scientific Press. 131

Alekseeva R E, Gratsianova R T, Elkin E A. 1970. Stratigraphy and Brachiopods of the Lower Devonian of Northeastern Salair (in Russian). Moscow: Scientific Press. 187

Alekseeva R E, Mendbayar B, Erlanger O A. 1981. Brachiopods and Biostratigraphy of Lower Devonian of Mongolia (in Russian). Moscow: Scientific Press. 176

Badarch G, Cuningham W D, Windley B F. 2002. A new terrane subdivision for Mongolia: Implications for the Phanerozoic crustal growth of Central Asia. J Asian Earth Sci, 21: 87-110

Bottjer D J. 2005. Geobiology and the fossil record: Eukaryotes, microbes, and their interaction. Palaeogeogr Palaeoclimat Palaeoecol, 219: 5-21

Boucot A J, Blodgett R B. 2001. Silurian-Devonian biogeography. In: Brunton C H C, Cocks L R M, Long S L, eds. Brachiopods Past and Present. Syst Ass Spec Vol, 63: 335-344

Boucot A J, Johnson J G, Talent J A. 1969. Early Devonian brachiopod zoogeography. Geol Soc Amer Spes Paper, 119: 1-45

Boucot A J. 1974. Silurian and Devonian biogeography. In: Ross Ch A, ed. Paleogeographic Provinces and Procinciality. Soc Econ Paleont Miner Spec Publ, 21: 165-176

Chen Z Q, Shi G R. 2000. Bashkirian to Moscovian (Late Carboniferous) brachiopod faunas from the Western Kunlun Mountains, Northwest China. Geobios, 33: 543-560

Chen Z Q. 2004. Lower Permian reef-dwelling brachiopod faunas from the Tarim Basin, Northwest China: Biostratigraphy, palaeoecology and biogeography. Palaeontographica Abt A, 272: 1-96

Chen Z, Archbold N W. 2000. Tournaisian-Visean brachiopods from the Gancaohu area of Southern Tianshan Mountains, Xinjiang, NW China. Geobios, 33: 183-199

Fredericks G. 1925. Upper Paleozoic of the Ussouriland, 2. Permian brachiopoa of cape Kalouzin (in Russian). Geol Com Russ Far East, 40: 1-27

Gordienko I V. 2006. Geodynamic evolution of Late Baikalides and Paleozoids in the folded Periphery of the Siberian Craton. Russian Geol Geophys, 47: 53-70

Gratsianova R T. 1967. Brachiopods and Stratigraphy of the Lower Devonian of the Mountainous Altai (in Russian). Moscow: Scientific Press. 176

Gretchishnikova I A. 1966. Stratigraphy and Brachiopods of the Lower Carbon of the Rudny Altai (in Russian). Moscow: Publishing Office Science. 184

Grunt T A. 1998. Conclusions. In: Grunt T A, Esaulova N K, Kanev G P, eds. Biota of East European Russia at the Early-Late Permian Boundary (in Russian). Moscow: GEOS. 355

Hallam A. 1981. Great Geological Controversies. New York: Oxford University. 182

Hamada T. 1971. Early Devonian brachiopods from the Lesser Khingan district of Northeast China. Palaontol Soc Japan Spec Paper, 15: 98

Hou H F, Boucot A J. 1990. The Balkhash-Mongolia-Okhorsk Region of the Old World Realm (Devonian). In: Mckerrow W S, Scotese C R, eds. Palaeozoic Palaeogeography and Biogeography. Geol Soc Memoir, 12: 297-303

Ivanova E A, Solovieva M N, Shik E M. 1979. The Moscovian stage in USSR and throughout the world. In: Wagner R H, et al. eds. Carboniferous of the USSR: Reports presented to IUGS subcommission on Carboniferous Stratigr. At the 8th Int Congr Carboniferous Stratigr Geol Yorkshire Geol Soc Occas Publ, 4: 11-146

Johnson J G, Boucot A J. 1973. Devonian Brachiopod Zoogeography. In: Hallan A, ed. Atlas of Palaeobiogeography. Amsterdam: Elsevier. 
89-96

Kalashnikov N V. 1980. Brachiopods of the Upper Palaeozoic from European Part of USSR (in Russian). Leningrad: Akademiia Nauk SSSR, Komi Filial Institut Geologii. 136

Kalashnikov N V. 1993. Permian brachiopods from the North of European Russia (in Russian). SPb: Наука. 151

Kalashnikov N V. 1998. Permian Spiriferids from the North of European Russia (in Russian). Moscow: GEOS. 138

Kaplun L I, Krupchenko N V. 1991. The Lower and Middle Devonian brachiopods of Dzhungaro-Balkhashskaya province. In: Dubatolov V N, Stukalina G A, eds. Biostratigraphy of the Lower and Middle Devonian of the Dzhungaro-Balkhashskaya Province (in Russian). Akademii Nauk SSSR, Sibirskoe Otdelenie, Institut Geoloogii i Geofiziki SOIUZASSR, Novosibirsk. 111-143

Khain V E. 1985. Geology of the USSR. First Part: Old Cratons and Paleozoic Fold Belts. Berlin: Gebrüder Borntraeger, Belin-Stuttgart. 272

Khodalevich A N. 1951. Early Devonian and Eifelian Brachiopods of Ivdel and Serov Areas in Sverdlovsk Province (in Russian). Moscow: State Publishing House of Gelogical Literature. 169

Kotlyar G V. 2002. Brachiopod. In: Kurylenko A V, Kotlyar G V, Kul'kov N P, et al., eds. Altas of the Paleozoic-Mesozoic Fauna and Flora in Transbaikalia (in Russian). Novosibirsk: Scientific Press. 220-249

Kulkov N P. 1963. The Brachiopoda of the Lower Devonian Solovikhin strata in the Gorny Altai (in Russian). Moscow: Publishing House of the Academy of Sciences of the USSR. 131

Kul'kov N P. 2002. Brachiopoda. In: Kurylenko A V, Kotlyar G V, Kul'kov N P, et al, eds. Altas of the Paleozoic-Mesozoic Fauna and Flora in Transbaikalia (in Russian). Novosibirsk: Scientific Press.106-138

Licharew B K, Kotlyyar G V. 1978. Permian brachiopods from southern Primorye (in Russian). In: Popeko L I, ed. Verkhnii Paleozoic Severo-Vostochnoi Asii. Dalnevostochnyi: Akad Nauk SSSR, Nauchnyi Tsentr Institut Tektonik i Geofiziki, Vladivostik. 63-99

Lieberman B S. 2005. Geobiology and paleobiogeography: tracking the coevolution of the Earth and its biota. Palaeogeogr Palaeoclimat Palaeoecol, 219: 23-33

Litvinovich N V. 1962. Carboniferous and Permian Deposits of the Western Region of Central Kazakhstan (in Russian). Moscow: Mosk Gos Univ. 389

Mironova M G. 1967. Upper Carboniferous Brachiopods from Bashkiria (in Russian). Leningrad: Old Lenin Gosud Univ AA Djanova. 62

Modzalevskaya E A, Kaplun L I, Rukavishnikova T B, et al. 1978. Brachiopoda. In: Rzhonsnitskaya M A, ed. Yarusnoe Raschlenenie Nizhnego Devona Tikhookeanskoi Oblasti na Territorii SSSR (in Russian). Moskva: 'Nedra'. 79-118

Mossakovsky A A, Ruzhentsev S V, Samygin S G, et al. 1993. Central Asia fold belt: Geodynamic evolution and formation history (in Russian). Geotectonics, 6: 3-32

Nalivkin D V. 1979. Brachiopods of the Tournaisian of the Urals (in Russian). Leningrad: Scientific Press. 248

Noffke N. 2005. Geobiology_A holistic scientific discipline. Palaeogeogr Palaeoclimat Palaeoecol, 219: 1-3

Oleneva N V. 2000. Brachiopods and Biostratigraphy of Devonian Deposits in Mongolian Altai Region (in Russian). Moscow: Scientific Press. 151

Pavlova E E, Manankov I N, Morozova I P, et al. 1991. Permian Invertebrates of Southern Mongolia (in Russian). Moscow: Scientific Press. 91-139

Prokofev V A. 1975. Late Carboniferous Brachiopods from Samara (in Russian). Moskva: Nedra Publishing House. 144

Sapelnikov V P, Rukavishnikova T B. 1975. Late Ordovician, Silurian and Early Devonian Pentamerid in Kazakhstan (in Russian). Moscow: Scientific Press. 225

Sarytcheva T G, Grigovieva A D, Nasikawova O N. 1968. Upper Palaeozoic branchiopods from west Kazakhstan (in Russian). Tr Palaeont Inst Akad Nauk SSSR, 121: 7-154

Sarytcheva T G, Sokolkaya A N, Beznosova G A, et al. 1963. Brakhiopody i Paleogeografiia Karbona Kuznetskoi Kotloviny (in Russian). Moscow: Akademiia Nauk SSSR, Trudy Paleontologicheskogo Instituta, 95. 454

Scotese C R, Mckerow W S. 1990. Revised World maps and introduction. In: Mckerow W S, Scotese C R, eds. Palaeozoic Palaeogeography and Biogeography. Geol Soc London, 12: 1-21

Shi G R, Shen S Z, Tazawa J I. 2002. Middle Permian (Guadalupian) brachiopods from the Xiujimqinqi area, Inner Mongolia, northeast China, and their palaeobiogeographical and palaeogeographical significance. Paleontol Res, 6: 285-297

Shi G R. 1998. Aspects of Permian marine biogeography: A review on nomenclature and evolutionary patterns, with patterns, with particular reference to the Asian-Western Pacific region. In: Permian Stratigraphy, Environments and Resources. Palaeoworld, 9: 97-112

Stehli F G, Grant R E. 1971. Permian brachiopods from Alex Heiberg Island, Canada, and an index of sampling efficiency. J Paleontol, 45: $502-521$ 
Stehli F G. 1973. Permian brachiopods. In: Hallam A, ed. Atlas of Paleobiogeography. London: Elsevier Scientific Publishing Company. $143-150$

Tazawa J, Chen Z Q. 2006. Middle Permian brachiopods from the Tumenling Formation in the Wuchang area, southern Heilongjiang, NE China, and their palaeobiogeographical implications. J Asian Earth Sci, 26: 327-338

Tjazheva A P, Zhavoronkova R A, Garifullina A A. 1976. Corals and Brachiopods of the Lower Devonian of the Southern Urals (in Russian). Moscow: Scientific Press. 226

Volgin V I. 1960. Brachiopoda of the Upper Carboniferous and Lower Permian deposits of Southern Fergana (in Russian). Zhdanov Leningr State Univ. 202

Wang C W, Li N, Sun Y W, et al. 2011. The distribution of Tuvaella brachiopod fauna and its tectonic significance. J Earth Sci, 22: 11-19

Wang C W, Li N, Zong P. 2012. Biogeographic characteristics of Zhesi brachiopod fauna and reconstruction of tectonopaleogeography of Jiamusi-Mongolia Block. Glob Geol, 15: 1-13

Wang C W, Zhang S M. 2008. Mechanism on bipolar distribution of Permian brachiopods. Glob Geol, 11: 59-77

Yin A, Nie S Y. 1996. A Phanerozoic palinspastic reconstruction of China and its neighboring regions. In: Yin A, Harrison T M, eds. The Tectonic Evolution of Asia. Cambridge: Cambridge University Press. 442-485

Zonenshain L P, Kuz'min M I, Natapov L M. 1990. Geology of the USSR: A plate tectonic synthesis. Geodynamics Series 21. Washington: American Geophysical Union. 242

Zorin Yu A, Belichenko V G, Turutanov E K, et al. 1995. The East Siberia Transect. Int Geol Rev, 37: 154-175 